bales and sank slowly to the ground. When the hobbles were finally secured he was turned on his back, some precautions were taken to prevent him choking, and the operation began. Compared with working on a shrivelled pickled specimen the whole thing was surprisingly easy, the tissues soft and labile, and the larynx seemingly as big as a three inch drain pipe. The instruments were correspondingly large: artery forceps 12 to 15 inches long, no delicate fingers needed.

After a sop to antisepsis Colonel Stewart demonstrated the approach to the living larynx with a six inch cut down the front. He did a Hobday on one side of the larynx. I did one on the other side to access its possibility to a tyro. It did not seem very easy for either of us and meant a good deal of local trauma, which is after all the object of that particular exercise.

On the second mule I demonstrated the simple operation that I had devised, and Colonel Stewart did the other side of that larynx. Between us we did the other mule and called it a day. No complications. No sewing up. The chloral drip was removed from the vein, the hobbles taken off, and everybody stood well clear. Within minutes-encouraged by a good deal of shouting from the orderlies-the mules struggled to their feet and were led drunkenly to the horse lines. We had a drink and inspected them soon afterwards.

The Hobdayed animal was looking a bit sick. A double Hobday in one morning is a bit much even for a mule. The other two were quietly munching hay. The question of the $£ 5$ write off did not arise.

I sent a detailed technical account of the operation to Colonel Stewart and visited him a little later in Agra to go through the technical details of the operation, and had a sight of the Taj Mahal enshrouded in scaffolding. Shortly afterwards I was posted elsewhere and heard no more of the project and did not discuss it. It was still supposed to be top secret. Some time later I heard indirectly from a Chindit organiser that the operation had been put into mass production and several thousand(?) animals had been treated with a high measure of success.

I kept a draft in longhand of the memo that I had sent to Colonel Stewart. It still must be somewhere. Apart from the technical detail in my original memo this is the only written account that $I$ have made of the events leading up to the silencing of the mules.

\title{
A pilot in the first world war
}

\author{
AUSTIN BRADFORD HILL
}

In 1915 I was at Chigwell School, in the Essex village of that name immortalised by Charles Dickens in Barnaby Rudge. I was head of the school, captain of football (soccer), in the cricket $\mathrm{XI}$, champion cross country runner-and a prig. I was nearly 18 years old and intended to follow my father, Sir Leonard Hill, FRS, into medicine. He sensibly suggested that I should leave school and do my first preclinical year before being called up for war service at the age of 19 . I would, no doubt, have gone to The London, where he had been professor of physiology before joining the newly founded Medical Research Council, as director of the department of applied physiology at the Hampstead Institute. I demurred. Though the risk was probably minute, it was not unknown in those days for good natured women to carry a white feather to offer to any healthy looking chap walking around in "civvies."

I preferred to stay on at school and in the meanwhile to apply for a commission in His Majesty's service. The question was which service-the Army or the Navy? There was as yet no Air Force. The Army had its own Royal Flying Corps and the Navy its Royal Naval Air Service. What attracted me to flying I have no idea. I had seen German Zeppelins caught in London's searchlights, held like long cigars in the night sky. I saw two shot down in flames. Perhaps I saw myself fighting the monstersI was too late, for with a machine gun fitted to an aircraft and tracer bullets their day was over. Then one day a pilot in the Royal Flying Corps flew low over the cricket field to impress his brother. In this he succeeded, for he touched a tree with his wing tip and crashed. He stepped unhurt from the wreckage. It was later that I was to be warned of this occupational hazard: "Show off to your girl friend and be scraped up with a spoon."

\section{Naval interview}

The Royal Flying Corps was said to be very "choosy" and, having a deaf ear (from measles in childhood), I decided to try

April Cottage, Lower Hopton, Nesscliffe, Shropshire SY4 1DL

SIR AUSTIN BRADFORD HILL, DSC, FRS, emeritus professor of medical statistics, London School of Hygiene and Tropical Medicine my luck with the Navy. So I went for a character interview and a medical examination. The only test of hearing I recall was the "forced whisper." An attendant turned down the flap of my deaf ear, the medical officer gave a four figure number in a forced whisper. I repeated it. Now for the crunch. Fortunately (for me) their coordination had not been perfected. The medical officer made his whisper a fraction of a second before the flap of my good ear was closed. Giving a slight pause I repeated the number. There I was, undeniably fit for flying duties.

In mid-1916 I was commissioned a flight sub lieutenant, RN, and posted to HMS Crystal Palace. This was the enormous glass building in south London (burned to the ground in 1936). It had been taken over by the Navy as a "battleship" for the entry and training of recruits. It was run as a battleship: we slung our hammocks, saluted the "quarter deck," applied for "shore leave" (to go into the West End), and were given an intensive two weeks of square bashing and physical exercises. I had been a sergeant in the officers training corps at school so I was good at drill, in both performance and taking charge of a squad. I was invited to stay on and undertake the duties of training others. But I wanted to fly and was posted to HMS Chingford, one of the two Royal Naval Air Service training schools. Here, a few miles from London on the edge of Epping Forest, the aerodrome was an expanse of watery fields crisscrossed with ditches covered over by wooden slats. Opposite was the huge King George V reservoir, across which the aircraft often had to take off. In retrospect it seems an odd choice for an aerodrome.

For the first two weeks a recruit did no flying. He absorbed the atmosphere (mainly of engine oil) and performed chores. The one which stays in my mind was the manhandling of aircraft into the hangers at the end of the day. A member of my group was Ivor Novello, later of musical comedy fame. To the tune that first brought him fame, "Keep the Home Fires Burning," we sang:

Keep poor B class stowing

Though the lorry's going

Though the lorry's due to leave

The aerodrome.

There's another Maurice

Waiting out there for us,

We must shove the damned thing in

Or we can't go home. 
Ivor was a great writer of tunes and an asset to the officers' mess. For his own, and others', safety his flying career was brief. At this time, too, one of the instructors was Ben Travers, the author of Rookery Nook and the many Aldwych farces. He once took a Maurice-Farman biplane and a shotgun in pursuit of a Zeppelin.

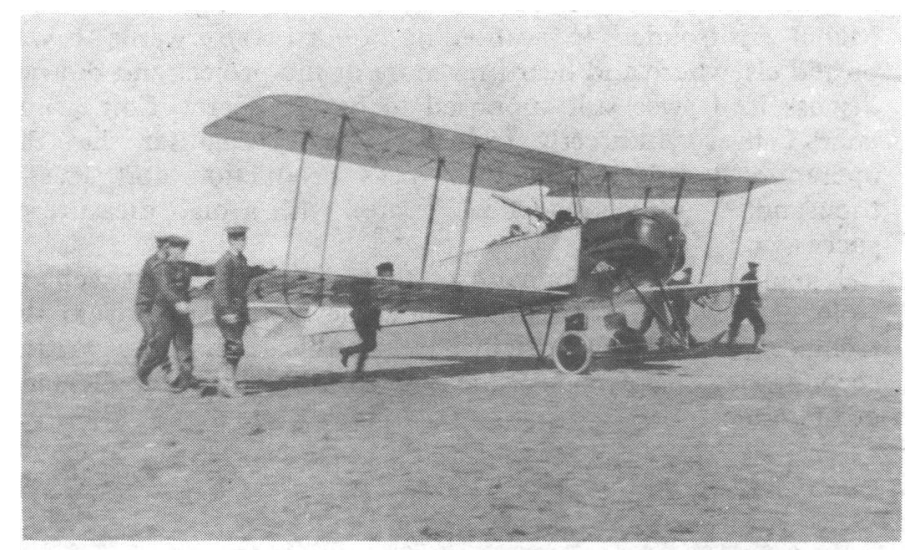

An Avro of the Royal Naval Air Service. Reproduced by permission of the Fleet Air Arm Museum, Yeovilton.

In learning to fly the philosophy of the day was that a little wind was a dangerous thing. Perhaps it was, with those fragile bits of wire, wood, and canvas. Accordingly, flying took place when the flag hung limply at the masthead. For my first lessons I was allocated to the Graham-White box kite. It was known as a "pusher" because the engine and propellor were placed on the lower wing behind the nacelle (polite word for box) in which the pilot sat. Thus he was pushed rather than pulled through the air. In the nacelle were the two controls: the "joy stick" for the hands and the rudder bar for the feet, and, so far as I remember, three instruments on the dash board-a revolution counter for the propeller, an altimeter, and an air speed indicator. The nacelle had no cover and, clothed in overcoat, fur helmet, gloves, and goggles, the pilot sat in the open air and peered over the edge. It was a biplane, as were all aircraft of the day, and driven by a rotary Gnome engine, in which the whole engine revolved along with the propeller (don't ask me why). In the teaching version there were seats for two and dual controls.

\section{Mastering the art}

In this contraption, with awe and an instructor, I set out to master the art of "straights." There was no self starter and the first object was to start the engine. This demanded a strict ritual between mechanic on the ground and pilot in the aircraft. "Switch on. ... Switch on." "Petrol on. ... Petrol on." "Suck in. ... Suck in." The mechanic would turn the propeller through a few revolutions. "Switch on. ... Switch on." He would then sharply force the propeller downwards and, with luck, the engine would start, the propeller would revolve, and the mechanic get his arm out of the way (not as difficult as it might sound).

"Chocks away.... Chocks away"-chocks were wooden blocks placed against the wheels to keep the aircraft from moving forward before the pilot was ready. A "straight" consisted of opening the throttle and speeding along the ground until the tail plane rose behind the pilot to the horizontal. With a nice judgment that "airspeed" had been reached the joystick was edged gently backwards and the machine left the ground. Then, when it had reached some 20 feet, one closed the throttle and landed again. At that time (and I guess now) the real skills in flying were called for at take off and at landing. In between, the control of the machine was relatively easy. In doing a "straight" the pilot certainly had to have his wits about him to co-ordinate this rapid take-off-landing manoeuvre. Circuits and bumps would seem easier but they came later.

The main difficulty of learning was the winter weather and the restriction to "no wind." So it took me 12 weeks with only six hours of actual, and spasmodic, flying before I undertook a solo straight, and nearly eight hours spread over 16 weeks before I was dispatched on a solo circuit-an acutely terrifying experience and the end of not a few flying careers. I saw many crashes but I cannot recall a death. The bits of wire, wood, and canvas fell to pieces with the greatest of ease, but, at the slow speeds at which we flew, the pilot in their midst often escaped serious injury.

I was now promoted to fly a more sophisticated machine-the Avro-and at the end of 1916 flew it, almost miraculously, for four hours in one week and over five hours in the next. I should have known that this was too good to last. I had taxied out to the far end of the aerodrome, turned to take off, and soared majestically above the hangars and the road and out over the King George V reservoir. At 200 feet the engine abruptly stopped. I had to go into the reservoir but if I had been sufficiently trained, or sufficiently intelligent, I could have glided in gently. I didn't. I hesitated a split second to consider what does " $A$ " do next. The machine lost flying speed, the weight of the engine took over, and I nosedived straight in. The aircraft disintegrated and was a write off. I escaped with a bloody nose and, in a mood of complete desolation, sat on the wing and awaited rescue.

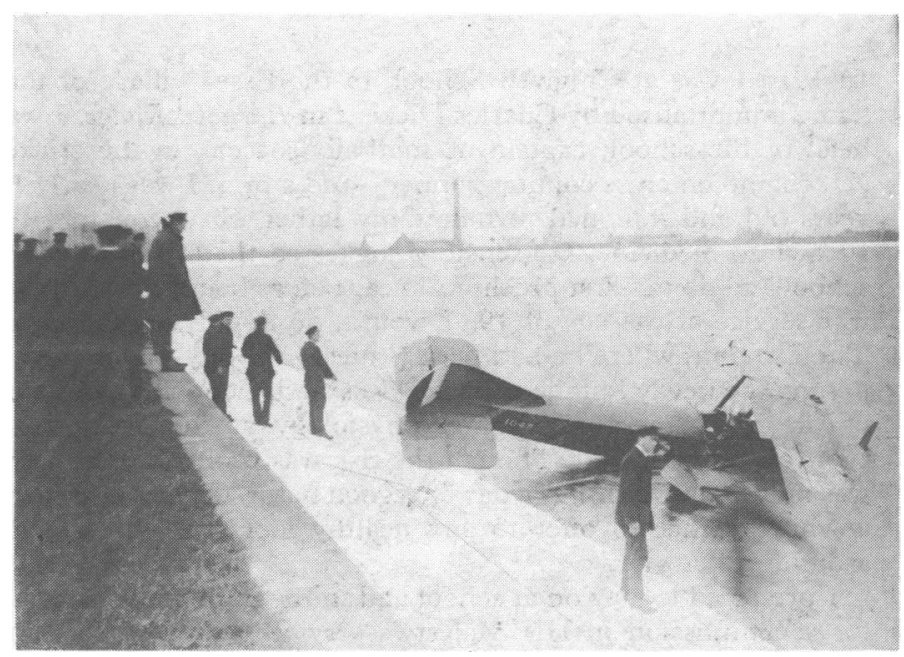

Rescuing my Avro from the reservoir.

To jump 65 years, Professor Donald Reid used this incident when inviting the Duke of Edinburgh to confer on me the honorary fellowship of the London School of Hygiene and Tropical Medicine.

"Sir Austin's career," he began, "did not begin well. He made his first, rather negative, contribution to the public health as a Sublieutenant in the Royal Navy Air Service in the first world war. He somehow succeeded in polluting London's water supply by crashlanding one of His Majesty's aircraft into a major reservoir. He then served in the Aegean, where he gallantly but unsuccessfully attempted to drop a bomb on the enemy fleet. Unfortunately, the string attaching the bomb to his aircraft was knotted and the Navy was cheated of another famous victory."

Well, later on I did drop a bomb in the Aegean; it was over the Dardanelles, in the darkness of the night, and what lay below me I have no idea. You never can tell where the poetic licence of the Scots highlander may lead. Nevertheless, it gave me the opportunity to tell His Royal Highness that at least half of Donald's speech was based on fact, and with that assurance, he showed willingness to confer the honour. 


\section{Ready for active service}

To return to 1916; I completed my training with some dummy bomb dropping and a few crosscountry jaunts (not too far, for we had no maps and no compass). Finally I looped the loop to mark my freedom and the fact that I was ready for "active service." The Fates, were kind, for in the spring of 1917 I was posted to East Fortune, a vast aerodrome south of Edinburgh and the home of airships (later the R34). The main task of the two aircraft pilots was to escort battleships down the Firth of Forth and, armed with bombs, to seek German submarines, which occasionally torpedoed merchant ships off the coast of St Abb's head some 20 miles away. I never saw one. Otherwise I was free to put in many hours of peaceful flying and thus to graduate to he was an other ranks and in those days regulations were strict.

The group then took train (a wartime train) to Paris, Modane, Rome, and finally Otranto at the toe of Italy. Jumbled together in a couple of dirty carriages we travelled, and tried to sleep, by night, and ran around the cities to see the sights by day. In Paris after some argument I suggested that we should visit Notre Dame. As we got out of our taxis there were horrified faces at the sight of "only a bloody church." I probably avoided such an error in Rome but I certainly took personal photographs of the Forum and the Colosseum. It was on this exhausting, overcrowded, and unhygienic journey that, I would guess, I picked up the tubercle bacillus, for I was conscious of a cough and malaise soon after arrival on the "fair isles of Greece." (Byron never had to live on them in huts made of aircraft packing cases.) We had finally reached them by ship from Otranto via Malta. I was posted to the island of Imbros a few miles from the Dardanelles. Our job was to patrol the straits, through which submarines were passing, and to keep bottled up two German battleships-the Goeben and the Breslau-which had remained there after the evacuation of our troops.

For a time I was sent to the tiny island of Tenedos, just off the Turkish coast, where I was expected to protect from bombing a battleship anchored there (I believe it was called a monitor). I carried out this task to perfection. The Turks naturally saw me arrive and ceased bombing until I went away. On only one occasion did I vacate my hammock and in the Sopwith Pup and pyjamas pursue an intruder. He was already streaking for home. But I had a machine gun synchronised to shoot through the revolutions of the propeller. With feelings of curiosity rather than hostility I pressed the button. It worked-but with no detriment to the Turk. It was on this island that I reached my closest to the real Navy. Indeed, I almost got too close for, as a naval officer, I was expected to take charge of the boat sent ashore to fetch me to dine in the officers' mess. With some qualms

the more advanced types of aircraft-the Bristol Bullet and the Sopwith Pup. One of the former turned upside down when a tyre burst at landing. I was left hanging head downwards, helpless but unharmed. On another occasion I took it up to 15000 feet, which without oxygen must have been a little unsafe. Anyway, the engine did not like it and packed up. I had a long glide down with the propeller hanging dead but no serious problem with the vast grassy expanse of aerodrome on which to land (we had no runways in those days).

From this station I frequently visited Sir Edward SharpeySchafer, the distinguished professor of physiology at Edinburgh University, who lived by the sea in North Berwick. In his garden we would play a game of bowls together and Lady Schafer provided a gorgeous tea. This wartime idyll, including 20 minutes aloft in a coastal airship, came to an end in June 1917, when I was posted to the Aegean. It was a remarkable journey. I joined a party of a dozen RNAS officers at Charing Cross Station, London, at 7 am to travel by train to Dover and by ship to Boulogne. Here I met my elder brother, who was a sergeant in the Royal Army Medical Corps working in a base hospital under the distinguished physician T R Elliot of University College Hospital and a member of the Medical Research Committee. We had some difficulty in hobnobbing for I was an officer and
I managed to steer in the right direction and was on the point of saying "If you chaps don't stop rowing we'll hit that ship" when the Petty Officer uttered the necessary warning "Way nuff." Ever after as I stepped aboard the boat I would say "Take charge, Petty Officer" and decline any further responsibility. On returning to Imbros I had a last argument with an aircraft-another engine failure (they were the bane of our lives). This occurred at 11000 feet; I had to glide down to that minute airstrip with a final approach across an enormous salt lake (shades of that damned reservoir). I misjudged by about 10 yards and landed on the muddy edge of the lake. The plane stood on its nose and broke its propeller (from the bits of best mahogany the station carpenter would make handsome souvenirs-walking sticks or cigarette cases).

Some five months after my arrival in the Aegean I made my last flight. I had a temperature of $100^{\circ} \mathrm{F}$ (I wonder how I got round to taking it ?). The tubercle bacillus was at last recognised. I was invalided home to die. In spite of all these heroic deeds the gods had no love for me. For, after being bedbound for nearly two years and having an artificial pneumothorax, a lung abscess, and two years of convalescence, I emerged to complete (at this

Two thirds of a century! But that is another story. time of writing) nearly 66 years of (officially) $100 \%$ disability. 